\title{
Characteristics and Outcomes of Patients With Primary Central Nervous System Lymphoma: A Single Center Experience and Review of the Literature
}

\author{
Serdal KORKMAZ ${ }^{1}$, Mehmet SENCAN ${ }^{1}$, Unal OZUM ${ }^{2}$, Ozen KARADAG ${ }^{2}$ \\ 'Cumhuriyet University Faculty of Medicine, Department of Hematology, Sivas \\ ${ }^{2}$ Cumhuriyet University Faculty of Medicine, Department of Neurosurgery, Sivas, TURKEY
}

\begin{abstract}
This retrospective study was designed to review the clinicopathological characteristics and outcomes of primary central nervous system lymphoma (PCNSL) cases at our institute. Patients diagnosed with PCNSL at our institute from August 2010 to December 2011 were evaluated. During this period, a total of 5 cases have been diagnosed with PCNSL. Parieto-occipital lobe was the most common site of involvement. Diffuse large B-cell lymphoma (DLBCL) was the most common histological pattern. 4 patients were treated with $3.0 \mathrm{~g} / \mathrm{m}^{2}$ methotrexate (MTX) intravenously concomitant with intraventricular $15 \mathrm{mg}$ MTX and 1 patient was treated with radiotherapy (RT). The median overall survival (OS) was 8 months (minimum: 1 months, maximum: 15 months) and mean OS was $8.4 \pm$ 5.41 months. As mentioned previous studies, MTX-based chemotherapy regimens are still the most effective treatment option in this patient population.
\end{abstract}

Keywords: Primary central nervous system lymphoma, Methotrexate, Radiotherapy, Overall survival

\section{ÖZET}

Primer Santral Sinir Sistemi Lenfomalı Hastaların Özellikleri ve Sonuçları: Tek Bir Merkez Deneyimi ve Literatür Özeti

Bu retrospektif çalışma bölümümüzdeki primer santral sinir sistemi lenfoma (PSSSL) vakalarının klinik ve patolojik özelliklerini ve sonuçlarını özetlemek için dizayn edildi. Ağustos 2010 ile Aralık 2011 tarihleri arasında, bölümümüzde PSSSL tanısı almış hastalar değerlendirildi. Bu zaman aralığında totalde 5 hasta PSSSL tanısı almıştır. En sık tutulan bölge parieto-oksipital lob idi. En sık histolojik tip diffüz büyük B hücreli lenfoma (DBBHL) idi. Hastaların dördü $3.0 \mathrm{~g} / \mathrm{m}^{2}$ intravenöz metotrexate (MTX) ve eş zamanII intraventriküler 15 mg MTX ile ve bir hasta da radyoterapi (RT) ile tedavi edildi. Ortanca tüm sağkalım 8 ay (minimum: 1 ay, maximum: 15 ay) ve ortalama tüm sağkalım $8.4 \pm 5.41$ ay idi. Daha önceki çalışmalarda bahsedildiği üzere MTX tabanlı kemoterapi rejimleri bu hasta grubunda halen en etkili tedavi şeklidir.

Anahtar Kelimeler: Primer santral sinir sistemi lenfoması, Metotrexate, Radyoterapi, Tüm sağkalım 


\section{INTRODUCTION}

PCNSL is a rare cancer accounting for less than 3\% of brain tumors.' The vast majority of PCNSLs are DLBCL. Unlike systemic lymphoma, durable remissions remain uncommon. The mean age of patients is approximately 60 years. ${ }^{2,3}$ Treatment for intra-cranial lymphoma can include chemotherapy, RT, surgery and a combination of these treatment modalities. ${ }^{4}$

Although combined chemotherapy and RT has produced response rates of up to $80-90 \%$ and median OS close to 5 years in PCNSL, ${ }^{5,6,7}$ neurocognitive toxicity has been a major limitation of this paradigm. ${ }^{8}$ Delayed neurotoxicity presents with memory deterioration and personality changes early in the course, followed by gait disturbance and urinary incontinence; these complications are generally permanent. ${ }^{8}$

The prognosis and outcome of treatment appears to differ between younger and older patients. Interestingly, the addition of radiation to the treatment regimen of elderly patients did not improve outcome when compared those who did not receive radiation. There is no consensus on the optimal combination regimen or dose of MTX.

Current treatment for PCNSL often involves highdose MTX (HD-MTX) based chemotherapy with or without whole brain radiotherapy (WBRT). MTX and WBRT each may cause CNS damage, but there appears to be synergistic toxicity when these two modalities are combined. ${ }^{910}$ This paper reviews our single center experience on patients with diagnosed PCNSL retrospectively.

\section{PATIENTS and METHODS}

Patients with PCNSL who were registered at our institute from August 2010 to December 2011 were evaluated. The study comprised of all the cases of histologically proven PCNSL diagnosed at the department of pathology between 2010 and 2011. The neurological tumor tissue for diagnosis has been obtained by stereotactic or craniotomy. Hematoxylin and eosin (H\&E) stained slides were reviewed. The complete clinical details were obtained from patient records. Age, sex, radiological findings, immune status, and human immunodeficiency virus (HIV) serology findings were recorded in every case. To exclude the possibility of secondary involvement by a systemic lymphoma, details pertaining to lymphadenopathy, organomegaly, and bone marrow study were also obtained. Cerebrospinal fluid (CSF) findings were recorded whenever available.

Patients: Five patients have been diagnosed as PCNSL with histological confirmation. Clinical data for all patients were available, and these patients constituted the study cohort. All patients had one or more intracranial mass lesions. Histological confirmation of PCNSL was required by the following: brain biopsy or open biopsy. To exclude evidence of systemic lymphoma, staging evaluation by neck, chest, abdominal, and pelvic computed tomography (CT) and by bone marrow biopsy has been performed. Four patients underwent cranial neuroimaging at diagnosis by magnetic resonance imaging (MRI). Only one underwent contrast-enhanced cranial CT because of hip prosthesis. Four patients underwent lumbar puncture and a complete ophthalmologic evaluation including a slit-lamp examination. And also, testicular ultrasonography has been performed in men patients. Before chemotherapy, no laboratory abnormalities were present, and laboratory diagnosis of a latent or obvious infection has been excluded.

Immunohistochemistry: Histological subtype of the tumor with grading of tumor cells on hematoxylin and eosin-stained slides, and immunohistochemical details, including typing for leucocyte common antigen (LCA), CD20 (B cell marker) and CD3 (T cell marker), performed on formalin-fixed, paraffin-embedded tissue samples, were recorded.

Treatment protocol: In DLBCL patients, treatment consisted of six cycles of chemotherapy administered at 28-day intervals, consisting of the following: MTX $3.0 \mathrm{~g} / \mathrm{m}^{2}$ for one day, followed by 15 doses of leucovorin rescue. At diagnosis, 4 patients underwent to Ommaya reservoir implantation and 6 courses of intraventricular MTX (15 mg) at 3-day cycle were administered to the patients. RT has been given only in one patient whom diagnosed with low grade lymphoma.

Follow-up: Repeat neuroimaging by MRI or CT was performed at the completion of 3 cycles of chemotherapy, and then the completion of 6 cycles of chemotherapy, and thereafter every 3 months. MRI 


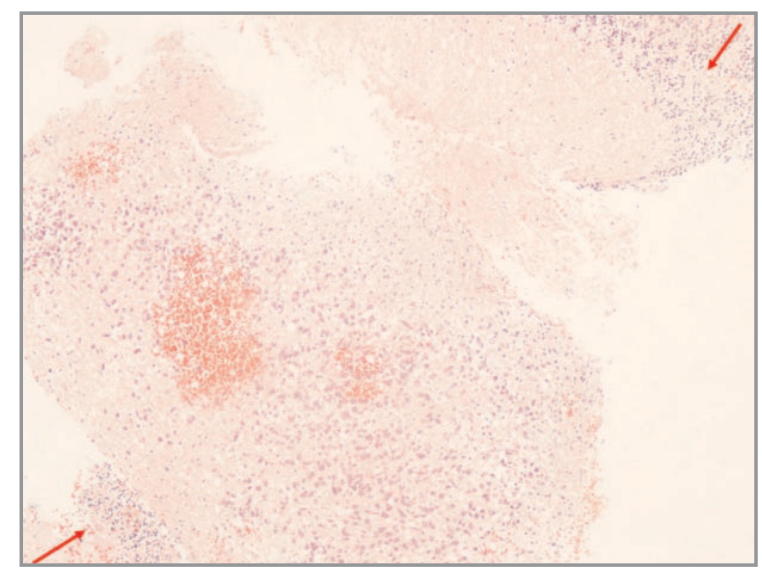

Figure 1. Cerebellar tissue (red arrows) and large scattered atypical lymphocytes (H\&E,X100). The tumor cells have round vesicular nucleus with multiple nuclei. The cells have scanty cytoplasm. There are seen characteristic lymphocytic infiltrates around vessels. [Immunhistochemically, LCA and CD20 positive; CD5, CD15, CD30, CD56, ER, PR, Chromogranin A, Synaptophysin, GFAP, CK7, GCDFP-15 and TTF-1 negative]

was performed using a $1.5 \mathrm{~T}$ clinical scanner. Basal ganglia, the corpus callosum, brain stem, and cerebellum were defined as deep brain structures. Peritumoral edema was categorized as $<$ or $\geq 2 \mathrm{~cm}$ from the brain tumor as assessed in T2-weighted MR images.

Evaluation of response to treatment: National Cancer Institute standardized response criteria regarding changes in the size of enhanced lesions on T1 weighted MR images were used to define treatment response. Complete remission (CR) was defined as the complete disappearance of all evidence of lymphoma; partial response (PR) as $\geq 50 \%$ decrease in tumor size; progressive disease (PD) as a $\geq$ $25 \%$ increase in tumor size or the appearance of any new lesion; and stable disease (SD) as situations that did not meet any of these three previous criteria.

Risk group was defined by the International Extranodal Lymphoma Study Group (IELSG) score. Using the prognostic scoring system devised by the IELSG, we categorized patients into three risk groups, namely, low, intermediate, and high. Variables included age, ECOG performance status grade, lactate dehydrogenase (LDH) serum level, protein concentration in CSF, and involvement of deep brain structures.

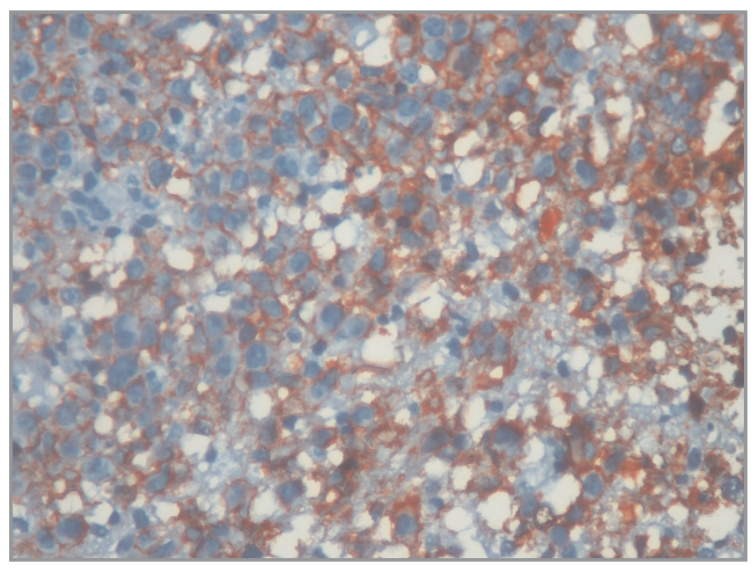

Figure 2. Tumor cells are positive with CD20 (CD20,x200)

Statistical methods: OS was calculated from the date of histological diagnosis to death or the last date of follow-up. Both median OS and mean OS was determined.

Ethics statement: The consent for this study has been obtained from Ethical Commitee of Cumhuriyet University Clinic Researchs.

\section{RESULTS}

\section{Patients and treatment}

The study group consisted of 5 patients, including 2 females and 3 males. All patients had at least one poor prognostic factor, and all of them were aged over 60 years (median age: 69 years). Lesions were single in four of the patients, and parieto-occipital region was the most common site of involvement. In one patient, MRI showed multipl site of involvement. Cerebellar involvement is very rare in PCNSL. In one patient, we obtained this type of involvement (Figure 1, 2, 3). Four of the patients diagnosed with DLBCL, and one was low grade B cell lymphoma. CSF involvement was not seen in obtained samples. Serum LDH levels were elevated in all patients. B2-microglobulin was elevated in three samples. Characteristics of patients were summarized in Table 1. Three of them received 6 cycles of HD-MTX, but one patient was in stable disease after 3 cycles of HD-MTX, so performed RT as a salvage regimen. Intraventricular chemotherapy were given to four patients. In low grade B cell lymphoma patient, RT was planned to cranium in a fraction of 20 at a dose of $36 \mathrm{~Gy}$ in totally. 


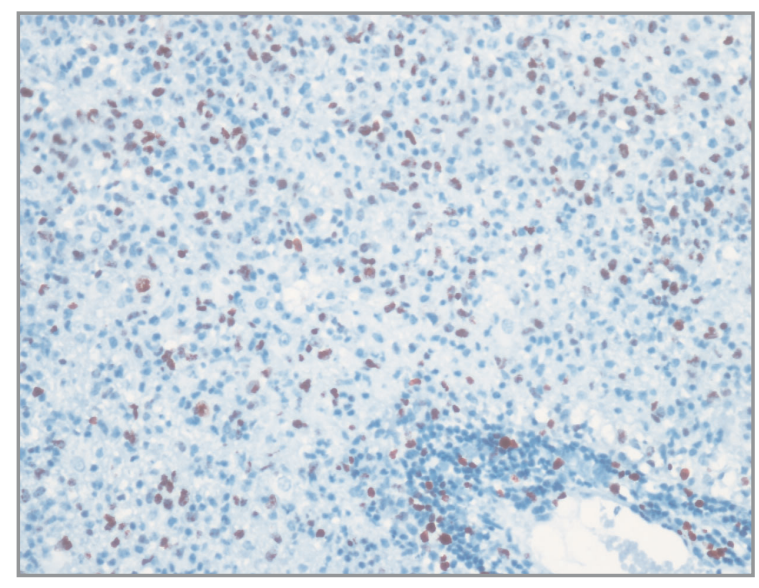

Figure 3. Ki-67 index is 50\% (Ki-67,x100).

Response to treatment: Of 5 patients, 4 (80\%) initially received HD-MTX at a dose of $3.0 \mathrm{~g} / \mathrm{m} 2$. CR occurred in $75 \%$ in the MTX group. CR was achieved after a median of 6 cycles of therapy. Response to MTX could not be reached in one patient. This patient who did not achieve a CR was in stable disease and received salvage RT. RT was given initially to one patient who was low grade B cell lymphoma, but she died at the 16 th day of the therapy because of her comorbide illnesses. Four patients additionally received 6 cycles of intraventricular chemotherapy. No recurrences have been obtained in the study population. No deaths were attributable to drug toxicity. Toxicities included pancytopenia, mucositis, and neurotoxicity. None of the patients ceased MTX therapy because of drug toxicity. Outcomes were summarized in Table 2.

Toxicity: Toxicity included grade $3 / 4$ hematotoxicity $(50 \%)$, and mucositis (25\%). These

toxicities were present after the HD-MTX therapy and they did not cause cessation of the treatment. Renal and liver toxicities were not seen in any patient. There was neurotoxicity only in one patient which was proven by MRI, but the patient did not exhibit any neurologic pattern clinically. And also, toxic death was not seen in the study group. The details about toxicity were outlined in Table 3 .

\section{DISCUSSION}

PCNSL is an aggressive lymphoma with poor prognosis and remains incurable in most patients. ${ }^{11}$ This retrospective study was undertaken to evaluate the

\begin{tabular}{|c|c|c|c|}
\hline \multicolumn{4}{|c|}{ Table 1. Patient characteristics } \\
\hline & $\begin{array}{l}\text { Total } \\
(n=5)\end{array}$ & $\begin{array}{l}\text { HD-MTX } \\
(n=4)\end{array}$ & $\begin{array}{l}\text { Radiothe- } \\
\text { rapy }(n=1)\end{array}$ \\
\hline \multicolumn{4}{|l|}{ Age } \\
\hline Median (years) & 69 & $60-80$ & 58 \\
\hline Range (years) & $60-80$ & 61 & 61 \\
\hline \multicolumn{4}{|l|}{ Gender } \\
\hline Female & 2 & 3 & 1 \\
\hline Male & 3 & 1 & - \\
\hline \multicolumn{4}{|l|}{ Lesions } \\
\hline Single & 4 & 1 & 3 \\
\hline Multiple & 1 & 1 & - \\
\hline \multicolumn{4}{|l|}{ Surgical procedure } \\
\hline Stereotactic biopsy & 3 & 1 & - \\
\hline Open biopsy & 3 & 1 & - \\
\hline Tumor resection & - & - & - \\
\hline \multicolumn{4}{|l|}{ Pathology } \\
\hline Diffuse Large B cell & 4 & 1 & 4 \\
\hline Other & - & - & 1 \\
\hline \multicolumn{4}{|l|}{ LDH } \\
\hline Elevated & 5 & 4 & 1 \\
\hline Normal & - & - & - \\
\hline \multicolumn{4}{|l|}{ B-2 Microglobulin } \\
\hline Elevated & 3 & 2 & 1 \\
\hline Normal & 2 & 2 & - \\
\hline \multicolumn{4}{|l|}{ CSF cytology } \\
\hline Negative & 4 & 4 & - \\
\hline Positive & - & - & - \\
\hline Not performed & 1 & - & 1 \\
\hline \multicolumn{4}{|l|}{ IELSG score: } \\
\hline $0-1$ & - & - & - \\
\hline $2-3$ & - & - & - \\
\hline $4-5$ & 5 & 4 & 1 \\
\hline $\begin{array}{l}\text { HD-MTX= high-dose } \mathrm{m} \\
\text { nodal lymphoma study }\end{array}$ & $\begin{array}{l}\text { otrexat } \\
\text { up; CS }\end{array}$ & $\begin{array}{l}S G=\text { inter } \\
\text { arebrospin }\end{array}$ & $\begin{array}{l}\text { ional extra- } \\
\text { luid. }\end{array}$ \\
\hline
\end{tabular}

clinicopathological profile and outcomes of patients diagnosed as PCNSL in our institute. 5 cases of PCNSL have been diagnosed between August 2010 and December 2011. PCNSL can occur at all ages, but a peak in the sixth and seventh decades has been reported in the western countries among the immunocompetent patients. ${ }^{12,13}$ In our study, peak incidence was found in sixth to seventh decades. The median age of the patients was 69 years and 


\begin{tabular}{|lll|}
\hline $\begin{array}{l}\text { Table 2. Outcome of HD-MTX-based chemotherapy and } \\
\text { radiotherapy in PCNSL }\end{array}$ & $\begin{array}{l}\text { Radiotherapy } \\
(n=1)\end{array}$ \\
\hline & $\begin{array}{l}\text { HD-MTX } \\
(n=4)\end{array}$ & $0 / 1(0 \%)$ \\
Complete Remission & $3 / 4(75 \%)$ & ${ }^{*}$ Not evaluated \\
Partial Remission & - & ${ }^{*}$ Not evaluated \\
Progressive Disease & - & *Not evaluated \\
Stable Disease & $1 / 4(\% 25)$ & \\
\hline * The patient has died at the 16 th day of radiation therapy
\end{tabular}

male-to-female ratio was $3 / 2$. Bataille et al. ${ }^{12}$ analyzed 248 cases of PCNSL in immunocompetent patients and the study involved 121 males and $127 \mathrm{fe}-$ male patients and the median age was 61 years. Reports suggest that this type of lymphoma occurs more commonly in men than women, in a ratio of 3:2 (men:women) as in our case. ${ }^{14}$

Intra-cranial lymphomas are diagnosed using both morphological criteria and immunohistochemical studies. Most primary intra-cranial lymphomas are comprised of non-Hodgkin's B-cells. CSF analysis yields a cytological diagnosis in fewer than half of patients with B-cell PCNSL. Neuro-imaging modalities can also reveal solitary lesions, which are most commonly located supra-tentorially, in the white matter of the frontal or parietal lobes or in the sub-ependymal regions. Sarkar et al..$^{15}$ have reported frontal lobe as the most common location in their study. In our study, two of the lesions were located in the parieto-occipital region. One lesion was in the occipital, the other one was in frontal lobe, and last one was located in cerebellar region which is very rare.

The vast majority of PCNSLs are DLBCL. In our study, 4 of the cases were classified as high grade, DLBCL which was the predominant histological type in other studies and one was low grade lymphoma. In our study, none of the tumor cells involved CSF in obtained samples. In our study, all the cases were immunocompetent with no HIV positive case.

Age and performance status are universally accepted as prognostic factors. Ferreri et al. ${ }^{16}$ have provided new understanding in this area using multivari-

\begin{tabular}{|lll|}
\hline $\begin{array}{l}\text { Table 3. Toxicity of HD-MTX-based chemotherapy and } \\
\text { radiotherapy in PCNSL }\end{array}$ & $\begin{array}{l}\text { HD-MTX } \\
(\mathrm{n}=4)\end{array}$ & $\begin{array}{l}\text { Radiotherapy } \\
(\mathrm{n}=1)\end{array}$ \\
\hline & $2(50 \%)$ & 0 \\
\hline $\begin{array}{l}\text { Anemia (grade 3/4) } \\
\text { Thrombocytopenia } \\
\quad \text { grade 3/4) }\end{array}$ & $2(50 \%)$ & 0 \\
Neutropenia (grade 3/4) & $2(50 \%)$ & 0 \\
Renal toxicity (grade 3/4) & 0 & 0 \\
Liver toxicity (grade 3/4) & 0 & 0 \\
Infections (grade 3/4) & 0 & 0 \\
Mucositis & $1(25 \%)$ & 0 \\
Neurotoxicity & $1(25 \%)$ & 0 \\
Toxic Death & 0 & 0 \\
\end{tabular}

ate analysis in a large cohort of patients with PCNSL. They revealed an independent association between OS and age, performance status, LDH serum concentration, CSF protein concentration and involvement of deep structures of the brain. A prognostic score, obtained by adding each of these variables (assigned a score of 0 or 1 , if absent or present), was significantly correlated with survival. Thus making it possible to distinguish low, intermediate and high risk groups. After analysing all of the patients, we observed that they all were in high risk group.

Treatment for intra-cranial lymphoma can include chemotherapy, RT, surgery and a combination of these treatment modalities. 4 In the elderly, chemotherapy alone is preferred since it has been described as effective as and less neurotoxic than RT or chemoradiotherapy. ${ }^{17}$ The introduction of MTX, a drug which penetrates the blood brain barrier effectively has improved median survival from 10 to 16 months to more than 30 months. ${ }^{18}$ In our study, the median OS was 8 months (min: 1 month, max: 15 months) and mean OS was $8.4 \pm 5.41$ months.

In an attempt to minimize acute and late toxicities in management of PCNSL, many studies have investigated the role of single-agent chemotherapy and deferred WBRT. Thus, MTX doses greater than $1 \mathrm{~g} / \mathrm{m}^{2}$ are considered necessary for adequate delivery to the CNS. ${ }^{19}$ Intraventricular chemotherapy 
attempts to improve CSF drug delivery; so, many studies of PCNSL included intrathecal/intraventricular chemotherapy. We bleeve that using singleagent chemotherapy together with intrathecal/intraventricular chemotherapy is the best therapy option in current clinical practice, especially in elderly population.

In conclusion, the PCNSL most commonly affects the sixth-seventh decades and DLBCL is the dominant histological pattern. Although chemotherapy as a single modality has an established role in the management of newly diagnosed PCNSL, a lot more randomized trials are warranted. It appears that single-agent high-dose MTX is working well with less toxicity. RT has been avoided in most patients given the neurocognitive toxicity, so it might be planned for relapse and/or refractory patients.

Acknowledgment: The authors would like to thank Ziynet CIINAR from the Department of Biostatistics, Cumhuriyet University School of Medicine, for her contributions to the study.

\section{REFERENCES}

1. Lee $\mathrm{CH}$, Jung $\mathrm{KW}$, Yoo $\mathrm{H}$, et al. Epidemiology of primary brain and central nervous system tumors in Korea. J Korean Neurosurg Soc 48:145-152, 2010.

2. Abrey LE, Ben-Porat L, Panageas KS, et al. Primary central nervous system lymphoma: the Memorial Sloan-Kettering Cancer Center prognostic model. J Clin Oncol 24: 5711-5715, 2006.

3. Ferreri AJ, Blay JY, Reni M, et al. Prognostic scoring system for primary CNS Iymphomas: the International Extranodal Lymphoma Study Group experience. J Clin Oncol 21: 266-272, 2003.

4. Dubuisson A, Kaschten B, Lénelle J, et al. Primary central nervous system lymphoma report of 32 cases and review of the literature. Clinical Neurology and Neurosurgery 107: 55-63, 2004.

5. Shah GD, Yahalom J, Correa DD, et al. Combined immunochemotherapy with reduced whole-brain radiotherapy for newly diagnosed primary CNS Iymphoma. J Clin Oncol 25: 4730-4735, 2007.

6. Gavrilovic IT, Hormigo A, Yahalom J, et al. Long-term follow-up of high-dose methotrexate-based therapy with and without whole brain irradiation for newly diagnosed primary CNS Iymphoma. J Clin Oncol 24: 45704574, 2006.

7. Omuro AM, DeAngelis LM, Yahalom J, Abrey LE. Chemoradiotherapy for primary CNS Iymphoma: an intentto-treat analysis with complete follow-up. Neurology 64: 69-74, 2005
8. Abrey LE, Yahalom J, DeAngelis LM. Treatment for primary CNS Iymphoma: the next step. J Clin Oncol 18: 3144-3150, 2000.

9. Correa DD, DeAngelis LM, Shi W, et al. Cognitive functions in survivors of primary central nervous system lymphoma. Neurology 62: 548-555, 2004.

10. Crossen JR, Garwood D, Glatstein E, Neuwelt A. Neurobehavioral sequelae of cranial irradiation in adults: a review of radiation-induced encephalopathy. J Clin Oncol 12: 627-642, 1994.

11. Deangelis LM, Iwamoto FM. An update on therapy of primary central nervous system lymphoma. Hematol Oncol Clin North Am 20: 1267-1285, 2006.

12. Bataille B, Delwail V, Menet E, et al. Primary intracerebral malignant lymphoma: A report of 248 cases. J Neurosurg 92: 261-266, 2000.

13. Basso $\cup$, Brandes AA. Diagnostic advances and new trends for the treatment of primary central nervous system Iymphoma. Eur J Cancer 38:1298-312, 2002.

14. Jaiswal AK, Mahapatra AK, Sharma MC. Primary central nervous system lymphoma presenting as bilateral cerebellopontine angle lesions: a rare case report. Journal of clinical neuroscience 11: 328-331, 2004.

15. Sarkar C, Sharma MC, Deb P, et al. Primary central nervous system lymphoma: A hospital based study of incidence and Clinicopathological feature from India (1980 -2003). J Neurooncol 71: 199-204, 2005.

16. Ferreri AJ, Guerra E, Regazzi M, et al. Area under the curve of methotrexate and creatinine clearance are outcome-determining factors in primary CNS lymphomas. Br J Cancer 90: 353-358, 2004.

17. Hoang-Xuan K, Taillandier L, Chinot $O$, et al. Chemotherapy alone as initial treatment for primary CNS Iymphoma in patients older than 60 years: a multicenter phase II study (26952) of the European Organization for Research and Treatment of Cancer Brain Tumor Group. J Clin Oncol 21: 2726-2731, 2003.

18. Plotkin SR, Batchelor TT. Primary nervous-system lymphoma. Lancet Oncol 2: 354-365, 2001.

19. Blay JY, Conroy T, Chevreau C, et al. High-dose methotrexate for the treatment of primary cerebral lymphomas: analysis of survival and late neurologic toxicity in a retrospective series. J Clin Oncol 16: 864-871, 1998.

\section{Correspondence}

Dr. Serdal KORKMAZ

Cumhuriyet Üniversitesi Tıp Fakültesi

Hematoloji Bilim Dalı

58140, Sivas / TURKEY

Tel: (+90.346) 2580939

Fax: (+90.346) 2581305

e-mail: srdlkorkmaz@mynet.com 